\title{
ACE2 correlated with immune infiltration serves as a prognostic biomarker in endometrial carcinoma and renal papillary cell carcinoma: implication for COVID-19
}

\author{
Jing Yang ${ }^{1}$, Hongxia $\mathrm{Li}^{1}$, Shengda Hu${ }^{1}$, Yafeng $\mathrm{Zhou}^{1}$ \\ ${ }^{1}$ Department of Cardiology, The First Affiliated Hospital of Soochow University, Suzhou 215006, China
}

Correspondence to: Yafeng Zhou; email: zhouyafeng70@126.com

Keywords: COVID-19, SARS-CoV-2, ACE2, immune infiltration

Received: March 11, $2020 \quad$ Accepted: April 4, 2020

Published: April 27, 2020

Copyright: Yang et al. This is an open-access article distributed under the terms of the Creative Commons Attribution License (CC BY 3.0), which permits unrestricted use, distribution, and reproduction in any medium, provided the original author and source are credited.

\section{ABSTRACT}

Angiotensin-converting enzyme 2 (ACE2) is a member of the renin-angiotension system, however, the correlation between ACE2 and prognosis in UCEC (Uterine Corpus Endometrial Carcinoma) and KIRP (Kidney Renal Papillary Cell Carcinoma) is not clear. We analyzed the expression levels of ACE2 in the Oncomine and TIMER databases, the correlation between ACE2 and overall survival in the PrognoScan, GEPIA and KaplanMeier plotter databases. The correlation between ACE2 and immune infiltration level and the type markers of immune cells was investigated in TIMER database. A prognosis analysis based on the expression levels of ACE2 was further performed in related immune cells subgroup. The ACE2 promoter methylation profile was tested in the UALCAN database. In addition, we used GSE30589 and GSE52920 databases to elucidate the changes of ACE2 expression in vivo and in vitro after SARS-CoV infection. ACE2 was elevated in UCEC and KIRP, and high ACE2 had a favorable prognosis. The expression of ACE2 was positively correlated with the level of immune infiltration of macrophage in KIRP, B cell, CD4+T cell, neutrophil and dendritic cell immune infiltration levels in UCEC. ACE2 was significantly positively correlated with the type markers of B cells and neutrophils, macrophages in UCEC, while ACE2 in KIRP was positively correlated with the type markers of macrophages. High ACE2 expression level had a favorable prognosis in different enriched immune cells subgroups in UCEC and KIRP. And the promoter methylation levels of ACE2 in UCEC and KIRP were significantly reduced. What's more, we found that the expression of ACE2 decreased in vivo and in vitro after SARS-CoV infection. In conclusion, ACE2 expression increased significantly in UCEC and KIRP, elevated ACE2 was positively correlated with immune infiltration and prognosis. Moreover, tumor tissues may be more susceptible to SARS-CoV-2 infection in COVID19 patients with UCEC and KIRP, which may worsen the prognosis.

\section{INTRODUCTION}

UCEC (Uterine Corpus Endometrial Carcinoma) is a common gynecological cancer in the world [1-3]. It is an epithelial malignant tumor of endometrium, which has a high mortality rate and seriously threatens the health of women $[4,5]$. It can be divided into two types: estrogen dependent and non estrogen dependent [6]. The incidence of non estrogen dependent tumors is low, but the malignancy is high and the prognosis is poor [4, 7]. The prognoses of endometrial cancer patients with metastasis are poor regardless of grade or stage, and the overall survival rate of patients is significantly reduced [8]. There is evidence that microsatellite unstable endometrial cancer has infiltration of granzyme B + cells, activated cytoxic T-lymphocytes, and PD-L1 + cells [9], which suggests that endometrial cancer can be treated with immunotherapy to improve prognosis.

KIRP (Kidney Renal Papillary Cell Carcinoma) accounts for $15 \%-20 \%$ of renal cancer [10]. KIRP is a malignant parenchymal tumor of the kidney, which is 
characterized by a papillary or tubular papillary structure [11]. It can be divided into type 1 and type 2 according to the histologic features, and type 2 KIRP has a high grade, a late stage and a poor prognosis [12, 13]. Moreover, the immune cell response is closely connected with the clinical prognosis of KIRP, and tumor related macrophages can represent the indicator of good prognosis of KIRP [14, 15]. Thus, it is necessary to clarify the relationship between UCEC and KIRP and immune invasion, and find an immune related biomarker to indicate the prognosis of UCEC and KIRP.

Angiotensin-converting enzyme 2 (ACE2) is a member of the renin-angiotension system. It's open reading frame encodes a polypeptide containing 805 amino acids [16]. The extracellular surface of ACE2 enzyme contains a catalytic metal peptidase domain, which has $42 \%$ sequence homology with the $\mathrm{N}$-terminal catalytic domain of ACE [17]. ACE2 mainly splits angiotensin II (ANG II) into angiotensin-(1-7) and acts as a vasodilator in the renin-angiotension system [18]. A recent study has shown that it can block the angiogenesis, tumor cell growth and metastasis of pancreatic cancer, breast cancer and colon cancer [19-21]. But the related prognosis and possible immune mechanisms of ACE2 in UCEC and KIRP are still ambiguous.

Since December 2019, coronavirus disease 2019 (COVID-19) was found in Wuhan City, Hubei Province, China [22]. It is caused by severe acute respiratory syndrome coronavirus 2 (SARS-CoV-2, previously tentatively named 2019-nCoV), which belongs to the beta coronaviruses $(\beta-\mathrm{CoV})$ genus [23]. SARS-CoV-2 and severe acute respiratory syndrome coronavirus (SARS-CoV) have 79.5\% homologous sequences, and it uses ACE2 as receptor to enter the cell like SARS-CoV [24]. As of March 4, 2020, there were 80409 laboratory confirmed cases and 3012 dead cases of COVID-19 in China [25]. It has been widely spread all over the world, and has been recognized as a public health emergency of international concern by the World Health Organization [26]. However, the prognosis of COVID-19 patients with UCEC and KIRP are still unclear.

In this study, we first analyzed the expression of ACE2 in different tumors in the oncomine and Tumor Immune Estimation Resource (TIMER) databases, and then used the PrognoScan, GEPIA and Kaplan-Meier plotter databases to study the prognostic relationship between ACE2 and various tumors. After screening tumors prognosis related to ACE2, the relationship between ACE2 and immune infiltration levels in different tumors was investigated in the Timer database. The ACE2 promoter methylation profile was also tested in the
UALCAN database. Besides, we made use of the GSE30589 and GSE52920 databases to clarify the changes of ACE2 in cells and animals following SARS$\mathrm{CoV}$ infection. Our findings shed light on the important role of ACE2 in UCEC and KIRP and also provided a potential mechanism related to immune infiltration in these tumors. It also illustrated the possible susceptibility of tumors to SARS-CoV-2 and prognosis of COVID-19 patients with UCEC and KIRP.

\section{RESULTS}

\section{The mRNA expression levels in human cancers}

In order to study the changes of ACE2 expression levels in different tumor tissues compared with normal tissues. We first analyzed Oncomine database, 11 databases including 739 samples were selected. The analysis showed that the expression levels of ACE2 in Invasive Breast Carcinoma, Esophageal Cancer, Head and Neck cancer, Liver cancer, Lung cancer and other cancer (Testicular Intratubular Germ Cell Neoplasi) increased significantly, while in breast cancer (Intraductal Cribriform Breast Adenocarcinoma and Invasive Breast Carcinoma), colorectal cancer, Esophageal Cancer, kidney cancer, Lymphoma, other cancer (Yolk Sac Tumor, Seminoma, Mixed Germ Cell Tumor, Embryonal Carcinoma, Testicular Embryonal Carcinoma, Testicular Yolk Sac Tumor, Testicular Seminoma, Uterine Corpus Leiomyoma, Malignant Fibrous Histiocytoma), pancreatic cancer and sarcoma decreased significantly (Figure 1A). The detailed results were summarized in Supplementary Table 1.

Then, we further studied the expression levels of ACE2 between different tumors and normal tissues based on the RNA-seq data of malignant tumors in TCGA database. The expression levels were higher in KIRP (Kidney Renal Papillary Cell Carcinoma) and UCEC (Uterine Corpus Endometrial Carcinoma) (Figure 1B). In addition, the expression level was also higher in LUAD (Lung Adenocarcinoma) (Figure 1B). Nevertheless, the expression levels of ACE2 were lower in BRCA (Breast Invasive Carcinoma), KICH (Kidney Chromophobe), LIHC (Liver Hepatocellular Carcinoma), PRAD (Prostate Adenocarcinoma), STAD (Stomach Adenocarcinoma) and THCA (Thyroid Carcinoma) (Figure 1B). We analyzed the above databases and found that the expression levels of ACE2 in breast cancer, eophagal cancer, kidney cancer, liver cancer and sarcoma were different due to different subtypes, most of which were lower than that in normal tissues except for liver cancer. What's more, ACE2 acts as a receptor for SARS-CoV-2 to enter cells, which means that tumor tissues that highly express ACE2 may be susceptible to SARS-CoV-2 infection. 
A

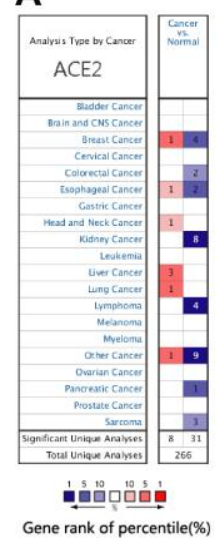

B

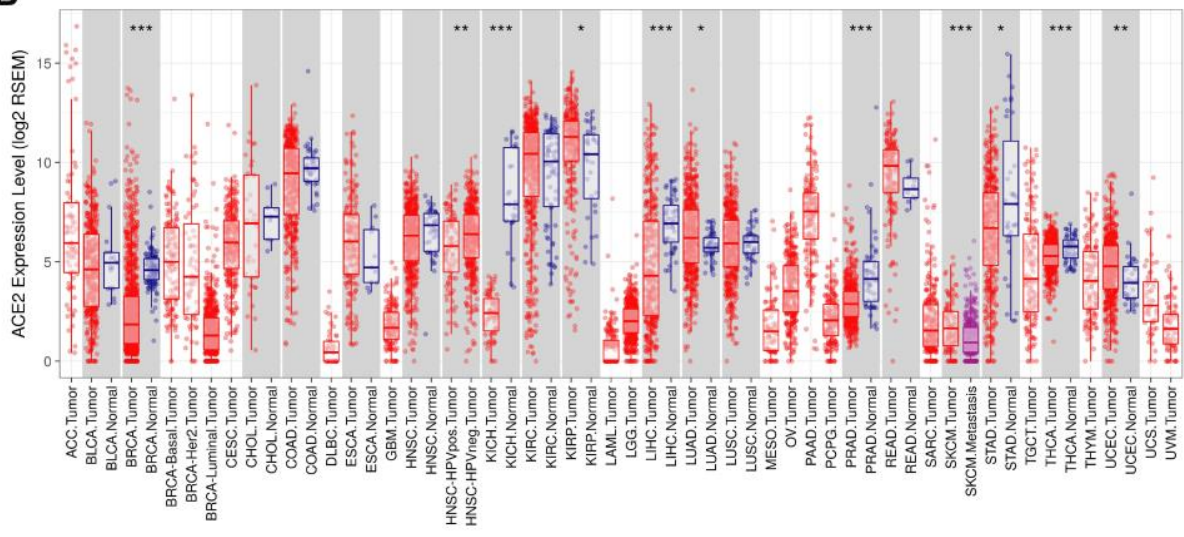

Figure 1. The expression levels of ACE2 in different cancers. (A) ACE2 in different cancers compared to normal tissues in the Oncomine database. (B) ACE2 expression levels of different tumor types in the TCGA database were detected by TIMER $\left({ }^{*} \mathrm{P}<0.05\right.$, ${ }^{* *} \mathrm{P}<0.01$, $\left.{ }^{* * *} \mathrm{P}<0.001\right)$.

A

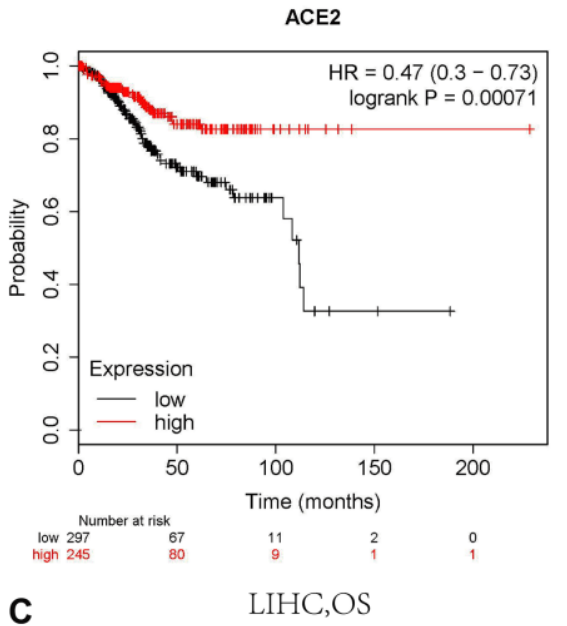

C

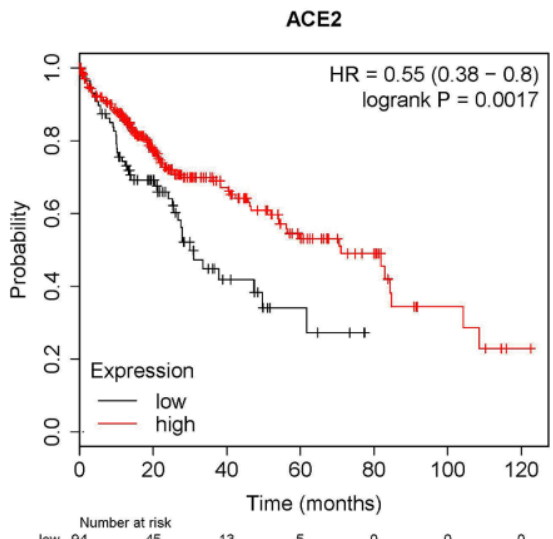

B KIRP,OS

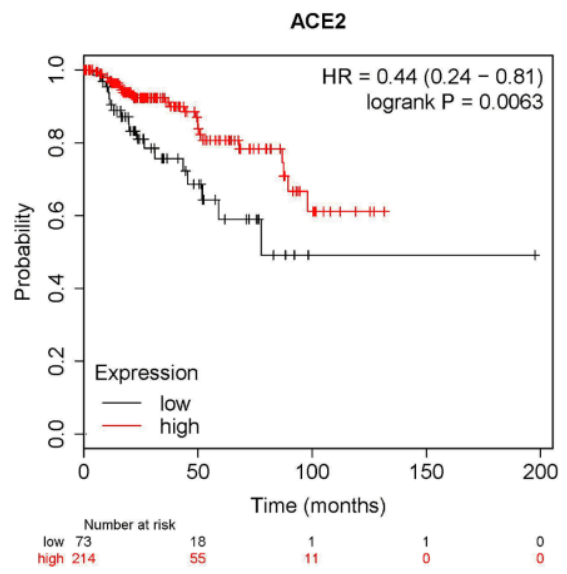

D

LUAD,OS

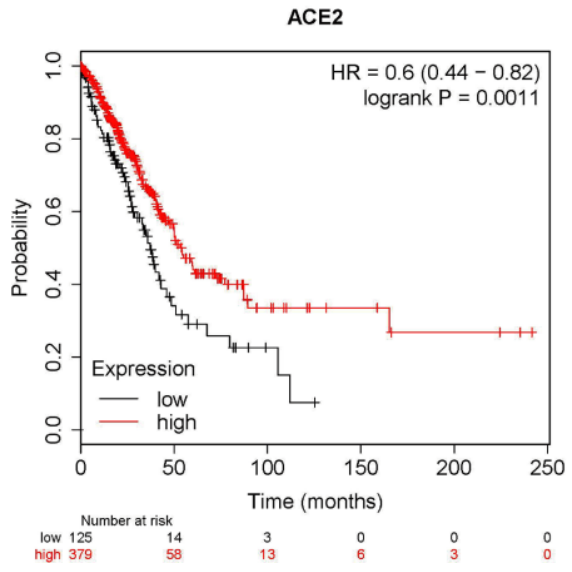

Figure 2. Comparison of Kaplan-Meier survival curves of ACE2 overexpression and underexpression in different cancers. (A) High ACE2 expression in the Kaplan Meier plotter database had favorable OS in UCEC ( $n=543)$, (B) KIRP ( $n=288),(C)$ LIHC ( $n=371)$ and (D) LUAD ( $n=513)$. OS, overall survival; UCEC, Uterine Corpus Endometrial Carcinoma; KIRP, Kidney Renal Papillary Cell Carcinoma; LIHC, Liver Hepatocellular Carcinoma; LUAD. Lung Adenocarcinoma. 


\section{ACE2 predicted prognosis in different cancers}

According to the difference of ACE2 expressions in some tumors, we further analyzed the relationship between ACE2 expression and prognosis in these tumors, so it is necessary to clarify whether ACE2 is the promoter or suppressor of tumors. PrognoScan was first used to study the relationship between the expression of ACE2 and the overall survival rate of different tumors. The analysis results showed that the high expression of ACE2 in breast cancer was related to the poor prognosis. However, the high expression of ACE2 in renal cell carcinoma had a favorable prognosis (Supplementary Table 2).

Then we analyzed TCGA database by GEPIA and explored the potential prognostic relationship between ACE2 expressions and human tumors. Interestingly, there was no significant relationship between the expressions of ACE2 and the prognosis of breast invasive carcinoma, kidney chromophobe, prostate adenocarcinoma, stomach adenocarcinoma, thyroid carcinoma, colon adenocarcinoma and head and neck squamous cell carcinoma (Supplementary Figure 1A$1 \mathrm{G)}$.

The Kaplan Meier plotter is a large database containing GEO, EGA and TCGA. It can be used as a tool to evaluate genes on survival in 21 cancer types. Therefore, we used the Kaplan Meier plotter to further check the relationships between ACE2 and prognoses of different tumors. ACE2 expressions have no significant correlations with the prognoses of breast cancer, head neck squamous cell carcinoma, stomach adenocarcinoma and thyroid carcinoma (Supplementary Figure $1 \mathrm{H}-1 \mathrm{~K}$ ). However, high ACE2 expression levels in uterine corpus endometrial carcinoma and kidney renal papillary cell carcinoma showed significant favorable prognoses (OS $\mathrm{HR} 0.47,95 \% \mathrm{CI}=0.30$ to 0.73 , OS HR0.44, $95 \% \mathrm{CI}=0.24$ to 0.81 , respectively) (Figure 2A, 2B). Similar prognoses were also observed in liver hepatocellular carcinoma and lung adenocarcinoma (Figure 2C, 2D).

\section{The transcription levels of ACE2 were correlated with tumor immune infiltration}

Previous studies had shown that tumor infiltration was related to the prognoses of renal cancer and endometrial cancer $[9,14,15]$. So, we tested whether the transcription levels of ACE2 in different tumors were correlated with immune infiltration. TIMER database was used to analyze the correlations between ACE2 level and uterine corpus endometrial carcinoma, kidney real papillary cell carcinoma, Liver hepatocellular carcinoma and lung adenocarcinoma. The results showed that ACE2 was very weakly negatively correlated with B cell, CD4 + T cell, dendritic cell and neutrophil of Liver hepatocellular carcinoma and lung adenocarcinoma (Supplementary Figure 2).

However, the expression of ACE2 was positively correlated with the level of immune infiltration of macrophage $(r=0.322, p<0.001)$ in kidney renal papillary cell carcinoma. Similarly, ACE2 has a positive correlation with $\mathrm{B}$ cell $(\mathrm{r}=0.166, \mathrm{p}<0.01), \mathrm{CD} 4+\mathrm{T}$ cell $(\mathrm{r}=0.154$, $\mathrm{p}<0.01)$, neutrophil $(\mathrm{r}=0.223, \mathrm{p}<0.001)$ and dendritic cell $(\mathrm{r}=0.271, \mathrm{p}<0.001)$ immune infiltration levels of uterine corpus endometrial carcinoma (Figure 3 ).

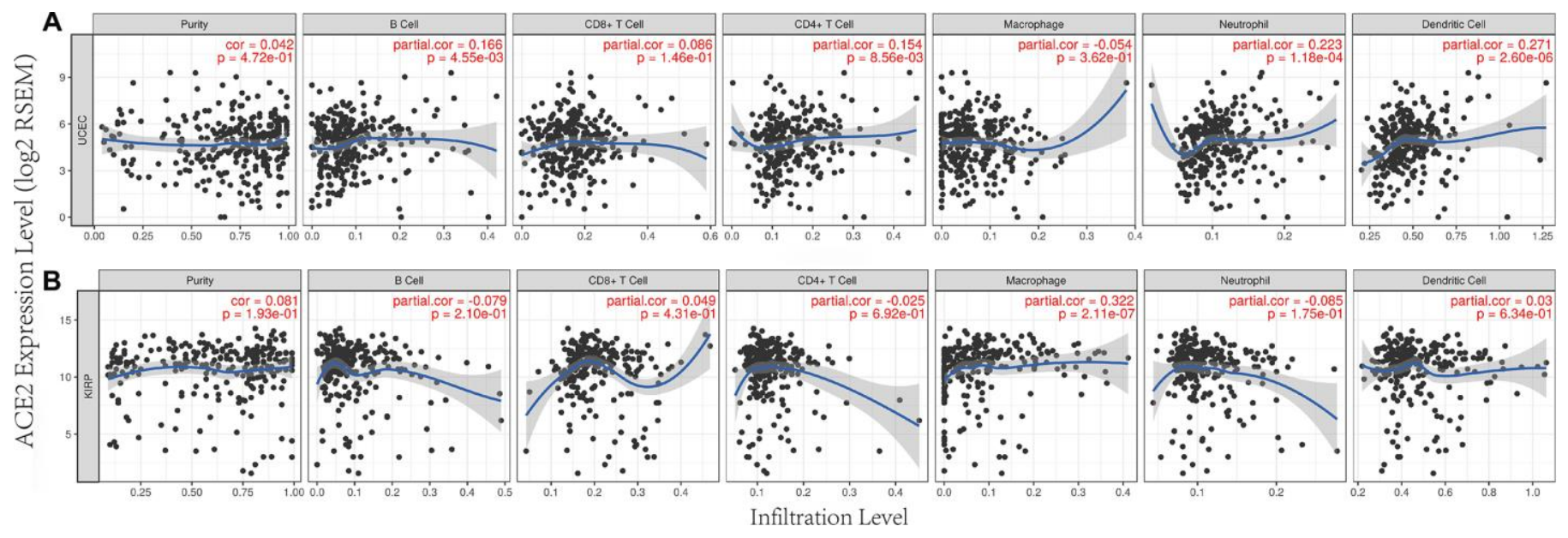

Figure 3. Correlation between ACE2 expression and immune infiltration in UCEC and KIRP in TIMER database. ACE2 expressions were positively correlated with (A) B cel, CD4 + T cell, neutrophil and dendritic cell immune infiltration levels of uterine corpus endofamilial carcinoma (UCEC), (B) the level of immune infiltration of macrophage in kidney renal papillary cell carcinoma (KIRP). 


\section{ACE2 expressions were correlated with immune cell type markers}

We further explored the relationships between the expressions of ACE2 and the type markers of different immune cells in endometrial and renal carcinoma. The type markers of B-cells, CD8 $+\mathrm{T}$ cells, neutrophils, macrophages, dendritic cells NK cells, Th1 cells, Treg cells and monocyte were analyzed by TIMER database.

The results showed that ACE2 in UCEC was positively correlated with FCRL2 and MS4A1 in B cells. ACE2 in UCEC was also positively correlated with FCGR3B, CEACAM3, SIGLEC5, CSF3R, S100A12 in neutrophils and CD84 in macrophages (Table 1). Similarly, ACE2 in KIRP was positively correlated with CD68 and CD84 in macrophages and C3AR1 in monocyte (Table 1). These correlations remained unchanged after tumor purity and age correction (Table 1). This further confirmed that ACE2 expressions in uterine corpus endofamilial carcinoma and kidney renal papillary cell carcinoma were correlated to immune infiltration.

\section{Prognostic analysis of ACE2 expressions in different tumors based on immune cells}

We have confirmed that the expressions of ACE2 were correlated with the immune infiltration in uterine corpus endometrial carcinoma and kidney renal papillary cell carcinoma, and the expressions of ACE2 were also related to the favorable prognoses of these tumors. So we speculated that the expressions of ACE2 in these tumors affected the prognosis partly because of immune infiltration.

We did a prognosis analysis based on the expression levels of ACE2 of different tumors in ralated immune cells subgroup via the Kaplan Meier plotter. The results showed that the high expression of ACE2 of uterine corpus endometrial carcinoma in enriched $\mathrm{B}$ cells $(\mathrm{HR}=$ $0.24)$, enriched CD4+ memory $\mathrm{T}$ cells $(\mathrm{HR}=0.28)$, enriched $\mathrm{CD} 8+\mathrm{T}$ cells $(\mathrm{HR}=0)$ and enriched macrophages $(\mathrm{HR}=0.09)$ cohort had better prognosis respectively (Figure 4A, 4C, 4E, 4G). Similarly, the high expression of ACE2 of Kidney Renal Papillary Cell Carcinoma had better prognosis in enriched regulatory $\mathrm{T}$ cells $(\mathrm{HR}=0.27)$ and enriched type $1 \mathrm{~T}$ helper cells ( $\mathrm{HR}=0.23$ ) cohort respectively (Figure 4I, $4 \mathrm{~K})$. But there was no significant correlation between the high ACE2 and the prognosis of Kidney Renal Papillary Cell Carcinoma in the enriched macrophages cohort (OS HR0.63, 95\% CI=0.3 to 1.3, logrank $\mathrm{P}=0.21$ ), and the high expressions of ACE2 of UCEC and KIRP had no significant correlation in decreased immune cells subgroup (Figure 4B, 4D, 4F, 4H, 4J, 4L). The above analysis suggested that high ACE2 expressions in UCEC and KIRP may affect prognoses in part due to immune infiltration.

\section{Promoter methylation levels of ACE2 decreased in UCEC and KIRP}

The significant increases of ACE2 expressions in UCEC and KIRP were observed. Therefore, we further studied the reason for the elevated ACE2. DNA methylation is an important event in the epigenetic modification of the genome and is closely related to the process of the disease [33]. In particular, hypomethylation can lead to genome instability [34, 35], and may activate related genes. So we used UALCAN database to verify the methylation levels of ACE2 promoter in UCEC and KIRP. Interestingly, the methylation levels of ACE2 promoter in UCEC and KIRP were significantly lower than that in normal tissue (Figure 5A, 5F). Also, we stratified UCEC and KIRP according to patients' age, individual cancer stages, tumor grade, tumor histology and nodal metastasis status.

The results showed that ACE2 promoter methylation levels of the older people, higher grade tumors and serous tumors groups were lower than control in UCEC (Figure 5B, 5D, 5E). Moreover, the ACE2 promoter methylation levels of tumors with lymph node metastasis group in KIRP were lower than that in normal tissue (Figure 5I). And the ACE2 promoter methylation levels of different individual cancer stage groups decreased significantly compared with normal tissues groups in UCEC and KIRP (Figure 5C, 5H). However, the ACE2 promoter methylation levels of ACE2 did not change significantly in different age subgroups of KIRP and individual cancer stages subgroups of UCEC and KIRP (Figure $5 \mathrm{C}, 5 \mathrm{G}, 5 \mathrm{H}$ ). It is suggested that ACE2 promoter hypomethylation in UCEC and KIRP may activate itself and increase its level respectively.

\section{SARS-CoV-2 infection may reduce the expression of ACE2}

ACE2 can be used as a receptor for SARS-CoV-2 to enter the cell [24]. It is necessary to study the changes of ACE2 in tumors after SARS-CoV-2 infection. Because SARS-CoV-2 and SARS-CoV have high homology [24], the change of ACE2 expression after cells or animals infected with SARS-CoV can be used as a reference for SARS-CoV-2. GSE30589 and GSE52920 databases were used to analyze the changes of ACE2 expression after SARS-CoV infected Vero E6 cells and mice lung. The results showed that the expressions of ACE2 in Vero E6 cells and mouse lung decreased significantly compared with control group (Figure 6). This finding suggested that ACE2 expression may decrease after SARS-CoV-2 infection. 
Table 1. Correlation analysis between ACE2 and immune cell type markers in TIMER database.

\begin{tabular}{|c|c|c|c|c|c|c|c|c|c|c|c|c|c|}
\hline \multirow{3}{*}{ Cell type } & \multirow{3}{*}{$\begin{array}{c}\text { Gene } \\
\text { markers }\end{array}$} & \multicolumn{6}{|c|}{ UCEC } & \multicolumn{6}{|c|}{ KIRP } \\
\hline & & \multicolumn{2}{|c|}{ None } & \multicolumn{2}{|c|}{ Purity } & \multicolumn{2}{|c|}{ Age } & \multicolumn{2}{|c|}{ None } & \multicolumn{2}{|c|}{ Purity } & \multicolumn{2}{|c|}{ Age } \\
\hline & & COR & $\mathbf{P}$ & COR & $\mathbf{P}$ & COR & $\mathbf{P}$ & COR & $\mathbf{P}$ & COR & $\mathbf{P}$ & COR & $\mathbf{P}$ \\
\hline \multirow[t]{3}{*}{ B cells } & FCRL2 & 0.325 & $6.7 \mathrm{E}-15$ & 0.290 & $4.4 \mathrm{E}-07$ & 0.331 & $2.9 \mathrm{E}-15$ & -0.046 & 4.4E-01 & -0.072 & $2.5 \mathrm{E}-01$ & -0.044 & 4.6E-01 \\
\hline & CD19 & 0.151 & $4.2 \mathrm{E}-04$ & 0.153 & $8.9 \mathrm{E}-03$ & 0.159 & $2.1 \mathrm{E}-04$ & -0.040 & $5.0 \mathrm{E}-01$ & -0.026 & $6.8 \mathrm{E}-01$ & -0.040 & 5.1E-01 \\
\hline & MS4A1 & 0.210 & 7.9E-07 & 0.231 & $6.6 \mathrm{E}-05$ & 0.217 & $3.6 \mathrm{E}-07$ & 0.043 & 4.7E-01 & 0.059 & $3.4 \mathrm{E}-01$ & 0.050 & 4.1E-01 \\
\hline \multirow[t]{2}{*}{ CD8+ T cells } & CD8A & 0.150 & 4.6E-04 & 0.152 & $9.4 \mathrm{E}-03$ & 0.149 & $5.0 \mathrm{E}-04$ & 0.059 & $3.2 \mathrm{E}-01$ & 0.038 & $5.5 \mathrm{E}-01$ & 0.064 & 2.9E-01 \\
\hline & $\mathrm{CD} 8 \mathrm{~B}$ & 0.161 & $1.7 \mathrm{E}-04$ & 0.159 & $6.5 \mathrm{E}-03$ & 0.158 & 2.3E-04 & 0.021 & $7.2 \mathrm{E}-01$ & 0.007 & $9.1 \mathrm{E}-01$ & 0.023 & 7.0E-01 \\
\hline \multirow[t]{6}{*}{ Neutrophils } & FCGR3B & 0.279 & $3.2 \mathrm{E}-11$ & 0.239 & $3.6 \mathrm{E}-05$ & 0.274 & $9.0 \mathrm{E}-11$ & 0.045 & 4.5E-01 & 0.037 & $5.5 \mathrm{E}-01$ & 0.048 & 4.2E-01 \\
\hline & CEACAM3 & 0.307 & $2.6 \mathrm{E}-13$ & 0.283 & $8.4 \mathrm{E}-07$ & 0.308 & $2.5 \mathrm{E}-13$ & -0.015 & $8.0 \mathrm{E}-01$ & -0.052 & $4.1 \mathrm{E}-01$ & -0.024 & $6.8 \mathrm{E}-01$ \\
\hline & SIGLEC5 & 0.210 & 7.7E-07 & 0.204 & $4.5 \mathrm{E}-04$ & 0.215 & 4.6E-07 & 0.171 & $3.5 \mathrm{E}-03$ & 0.146 & $1.9 \mathrm{E}-02$ & 0.172 & 3.6E-03 \\
\hline & FPR1 & 0.195 & 4.7E-06 & 0.187 & $1.3 \mathrm{E}-03$ & 0.199 & $3.1 \mathrm{E}-06$ & 0.081 & $1.7 \mathrm{E}-01$ & 0.037 & $5.6 \mathrm{E}-01$ & 0.071 & 2.3E-01 \\
\hline & CSF3R & 0.234 & $3.2 \mathrm{E}-08$ & 0.184 & $1.5 \mathrm{E}-03$ & 0.248 & $5.4 \mathrm{E}-09$ & 0.085 & $1.5 \mathrm{E}-01$ & 0.051 & $4.2 \mathrm{E}-01$ & 0.091 & $1.2 \mathrm{E}-01$ \\
\hline & S100A12 & 0.247 & $5.4 \mathrm{E}-09$ & 0.244 & $2.4 \mathrm{E}-05$ & 0.249 & 4.7E-09 & -0.087 & $1.4 \mathrm{E}-01$ & -0.113 & $7.0 \mathrm{E}-02$ & -0.079 & $1.8 \mathrm{E}-01$ \\
\hline \multirow[t]{4}{*}{ Macrophages } & CD68 & 0.189 & $9.1 \mathrm{E}-06$ & 0.173 & $3.0 \mathrm{E}-03$ & 0.196 & 4.3E-06 & 0.390 & $7.8 \mathrm{E}-12$ & 0.372 & 7.1E-10 & 0.388 & $1.3 \mathrm{E}-11$ \\
\hline & CD84 & 0.210 & 7.9E-07 & 0.194 & $8.3 \mathrm{E}-04$ & 0.216 & 3.9E-07 & 0.259 & $8.2 \mathrm{E}-06$ & 0.269 & $1.2 \mathrm{E}-05$ & 0.266 & $5.6 \mathrm{E}-06$ \\
\hline & CD163 & 0.094 & $2.8 \mathrm{E}-02$ & 0.092 & $1.2 \mathrm{E}-01$ & 0.102 & $1.7 \mathrm{E}-02$ & 0.180 & $2.1 \mathrm{E}-03$ & 0.173 & $5.2 \mathrm{E}-03$ & 0.173 & $3.5 \mathrm{E}-03$ \\
\hline & MS4A4A & 0.094 & $2.8 \mathrm{E}-02$ & 0.079 & $1.8 \mathrm{E}-01$ & 0.098 & $2.3 \mathrm{E}-02$ & 0.162 & $5.8 \mathrm{E}-03$ & 0.157 & $1.1 \mathrm{E}-02$ & 0.157 & 7.9E-03 \\
\hline Dendritic cells & CD209 & 0.077 & 7.4E-02 & 0.113 & $5.3 \mathrm{E}-02$ & 0.081 & $5.9 \mathrm{E}-02$ & -0.045 & $4.5 \mathrm{E}-01$ & -0.033 & $6.0 \mathrm{E}-01$ & -0.044 & 4.6E-01 \\
\hline \multirow[t]{2}{*}{ NK cells } & KIR3DL3 & 0.145 & $7.0 \mathrm{E}-04$ & 0.121 & $3.8 \mathrm{E}-02$ & 0.140 & $1.1 \mathrm{E}-03$ & -0.048 & $4.1 \mathrm{E}-01$ & -0.052 & $4.0 \mathrm{E}-01$ & -0.043 & 4.7E-01 \\
\hline & NCR1 & 0.186 & $1.2 \mathrm{E}-05$ & 0.137 & $1.9 \mathrm{E}-02$ & 0.181 & $2.3 \mathrm{E}-05$ & 0.039 & $5.1 \mathrm{E}-01$ & 0.032 & $6.0 \mathrm{E}-01$ & 0.035 & $5.6 \mathrm{E}-01$ \\
\hline Th1 cells & TBX21 & 0.132 & $2.1 \mathrm{E}-03$ & 0.123 & $3.6 \mathrm{E}-02$ & 0.135 & $1.7 \mathrm{E}-03$ & 0.069 & $2.4 \mathrm{E}-01$ & 0.056 & $3.7 \mathrm{E}-01$ & 0.060 & 3.2E-01 \\
\hline \multirow[t]{2}{*}{ Treg } & FOXP3 & 0.160 & $1.7 \mathrm{E}-04$ & 0.146 & $1.3 \mathrm{E}-02$ & 0.155 & 3.0E-04 & -0.095 & $1.1 \mathrm{E}-01$ & -0.110 & $7.8 \mathrm{E}-02$ & -0.085 & $1.5 \mathrm{E}-01$ \\
\hline & CCR8 & 0.165 & $1.1 \mathrm{E}-04$ & 0.149 & $1.1 \mathrm{E}-02$ & 0.158 & $2.2 \mathrm{E}-04$ & -0.014 & $8.2 \mathrm{E}-01$ & -0.046 & 4.7E-01 & -0.007 & $9.0 \mathrm{E}-01$ \\
\hline \multirow[t]{3}{*}{ Monocyte } & C3AR1 & 0.138 & $1.2 \mathrm{E}-03$ & 0.116 & 4.6E-02 & 0.143 & $8.8 \mathrm{E}-04$ & 0.231 & 7.6E-05 & 0.231 & $1.8 \mathrm{E}-04$ & 0.231 & 8.3E-05 \\
\hline & CD86 & 0.164 & $1.1 \mathrm{E}-04$ & 0.161 & $5.7 \mathrm{E}-03$ & 0.171 & $6.6 \mathrm{E}-05$ & 0.166 & 4.7E-03 & 0.153 & $1.4 \mathrm{E}-02$ & 0.166 & $5.0 \mathrm{E}-03$ \\
\hline & CSF1R & 0.147 & $5.6 \mathrm{E}-04$ & 0.150 & $1.0 \mathrm{E}-02$ & 0.150 & 4.6E-04 & 0.134 & $2.3 \mathrm{E}-02$ & 0.110 & 7.7E-02 & 0.132 & $2.6 \mathrm{E}-02$ \\
\hline
\end{tabular}

UCEC, Uterine Corpus Endometrial Carcinoma; KIRP, Kidney Renal Papillary Cell Carcinoma; NK cells, Natural killer cells; Th 1 cells, type I helper T cells; Treg, regulatory T cells; COR, r value of Spearman's correlation; Purity, correlation adjusted by purity; Age correlation adjusted by age.

\section{DISCUSSION}

In this study, the changes of ACE2 mRNA in UCEC and KIRP were analyzed in Oncomine and TIMER databases. And we analyzed the correlations between ACE2 expression levels and immune infiltration and the prognoses of these tumors. Moreover, we predicted the susceptibility of different tumor tissues to SARS-CoV-2 and the potential prognoses of patients after SARSCoV-2 infection in UCEC and KIRP.

We analyzed the TCGA database using TIMER database and found that ACE2 was elevated in both UCEC and KIRP (Figure 1B), which suggested that tumor tissues were more likely to be infected with SARS-CoV-2 in UCEC and KIRP. The Kaplan Meier plotter was used to investigate the effect of ACE2 on tumor prognosis, the results showed that high ACE2 had a favorable prognosis in UCEC and KIRP (Figure 2A, 2B). In addition, TIMER database was also used to analyze the correlation between ACE2 and immune infiltration in UCEC and KIRP. The results showed that ACE2 and B cell, CD $4+\mathrm{T}$ cell, neutrophil and dendritic cell infiltration levels were positively correlated in UCEC (Figure 3A). There was also a positive correlation between macrophage infiltration level and ACE2 in KIRP (Figure 3B). The immune cell type markers in UCEC and KIRP were further studied, after correction of tumor purity, ACE2 in UCEC was significantly positively correlated with FCRL2 and MS4A1 in B cells, it was also positively correlated with FCGR3B, CEACAM3, SIGLEC5, CSF3R and S100A12 in neutrophils and CD84 in macrophages, while ACE2 in KIRP was positively correlated with CD68 and CD84 in macrophages 
(Table 1). These strongly confirmed the positive correlation between ACE2 and immune infiltration in UCEC and KIRP. Prognostic analysis of ACE2 expression levels in different tumor based on immune cells was performed, high ACE2 expression level in UCEC had a favorable prognosis in the enriched $\mathrm{B}$ cells, CD4 + memory $\mathrm{T}$ cells, CD8 $+\mathrm{T}$ cells and macrophages subgroups (Figure 4A-4H), and high ACE2 expression in KIRP had a favorable prognosis in the enriched regulatory T cells and type $1 \mathrm{~T}$ helper cells subgroups (Figure 4I, 4K). The analysis suggests that the high expressions of ACE2 in UCEC and KIRP may affect the prognoses of cancer patients in part due to immune infiltration.

In order to explore the causes of elevated ACE2 in UCEC and KIRP, we investigated the level of methylation in UCEC and KIRP. Surprisingly, the promoter methylation levels of ACE2 in UCEC and KIRP were significantly reduced (Figure 5A, 5F). ACE2 may be activated and up-regulated due to its hypomethylation, which to some extent explained the elevated ACE2 in UCEC and KIRP. SARS-CoV-2 can use ACE2 as a receptor to enter cells, and it has high homology with SARS-CoV [24]. Therefore, we used the GSE30589 and GSE52920 databases to study the changes of ACE2 of Vero E6 cells and mouse that were infected with SARS-CoV. The results showed that ACE2 expression levels in both of them were reduced after SARS-CoV infection (Figure 6). This finding suggested that tumor tissues may also have decreased ACE2 levels after SARS-CoV-2 infection in UCEC and KIRP.

In the above analysis, ACE2 was confirmed to be elevated in UCEC and KIRP, Thus, after patients with UCEC and KIRP are infected with SARS-CoV-2, their tumor tissues are more susceptible to virus interference in addition to the respiratory system. Afterwards, tumor tissues infected with SARS-CoV-2 in turn underwent a decrease in ACE2, and reduced ACE2 brought about tumor microenvironment disorders because of reduced

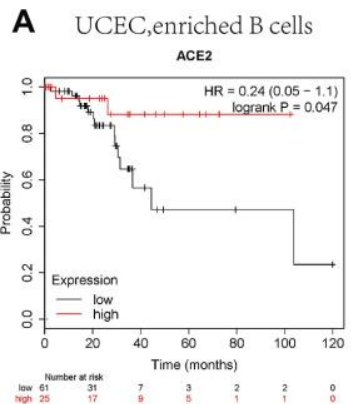

E UCEC,enriched CD8+ T cells

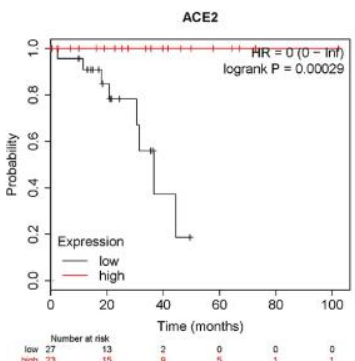

I KIRP,enriched Treg cells

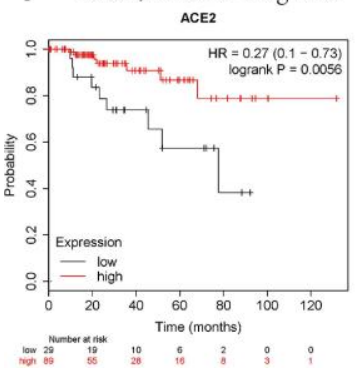

B UCEC,decreased B cells
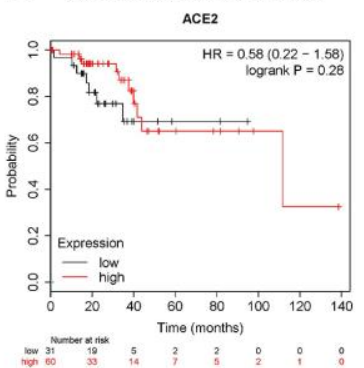

F UCEC,decreased CD8+ T cells

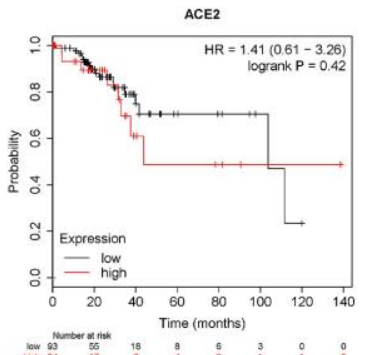

J KIRP,decreased Treg cells

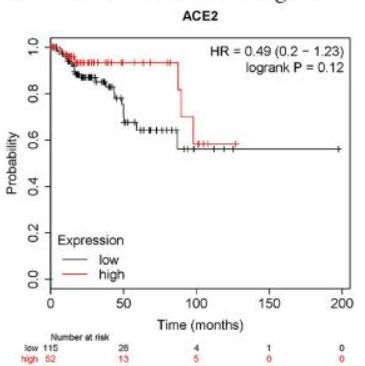

C UCEC,enriched $\mathrm{CD} 4+\mathrm{T}$ cells

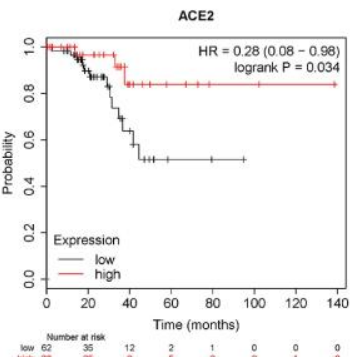

UCEC,enriched Macrophages ACE2

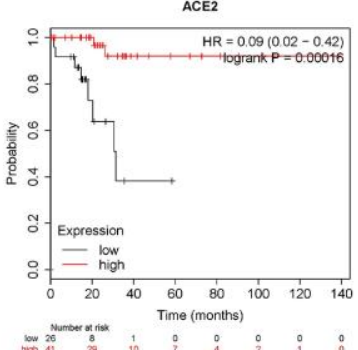

K KIRP,enriched Th1 cells

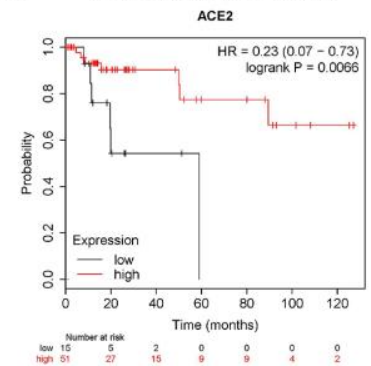

D UCEC,decreased CD4+ T cells

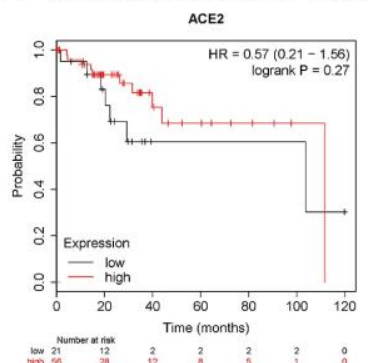

H UCEC,decreased Macrophages ACE2

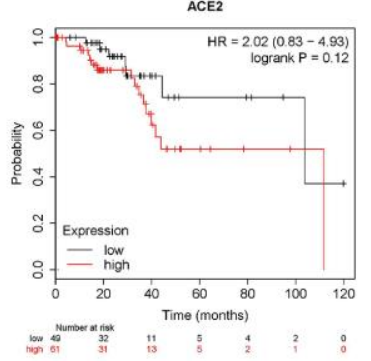

L KIRP.decreased Thl cells

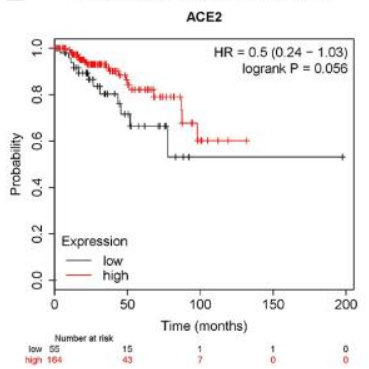

Figure 4. Comparison of Kaplan-Meier survival curves of the high and low expression of ACE2 in UCEC and KIRP based on immune cells subgroups. Relationships between ACE2 of different immune cells subgroup and prognoses in (A-H) Uterine Corpus Endometrial Carcinoma (UCEC), and (I-L) Kidney Renal Papillary Cell Carcinoma (KIRP). 
A

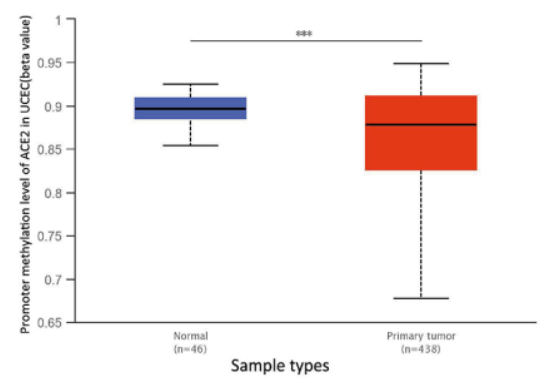

D

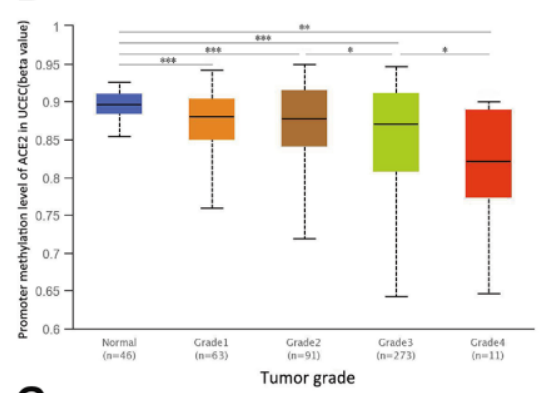

G

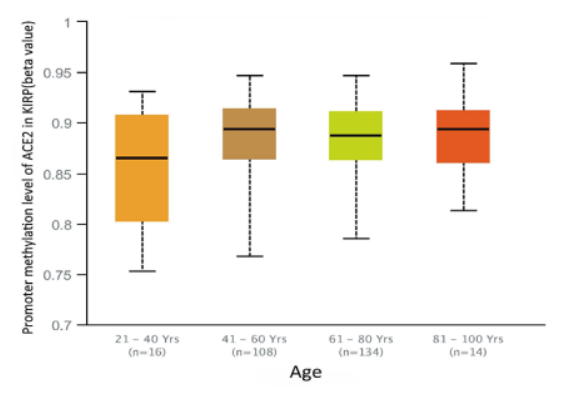

B

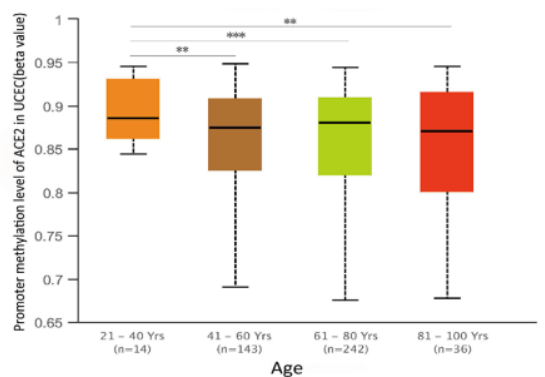

E

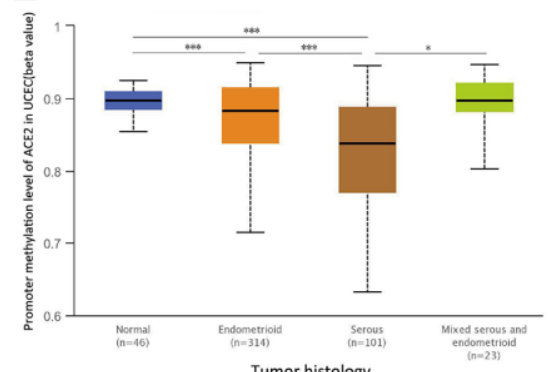

H

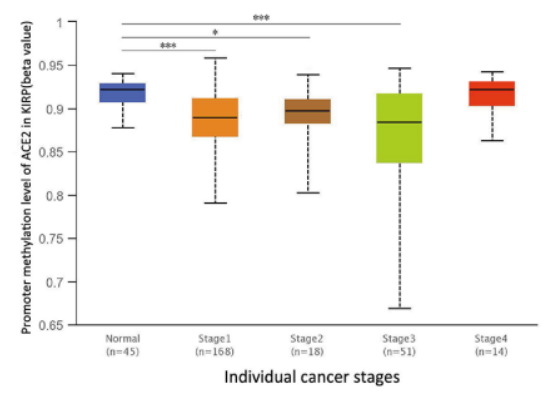

C

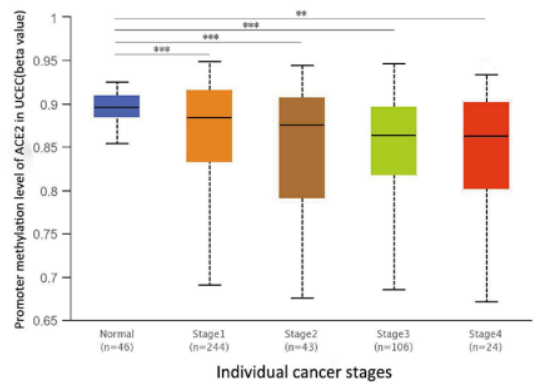

F

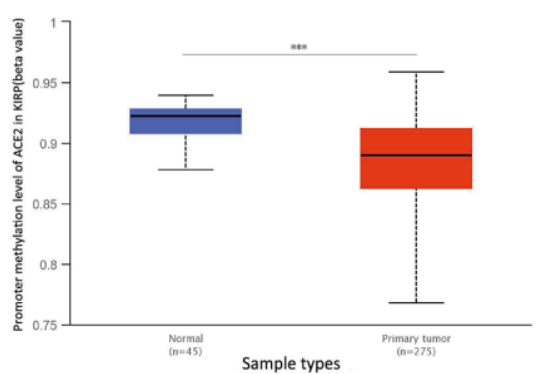

I

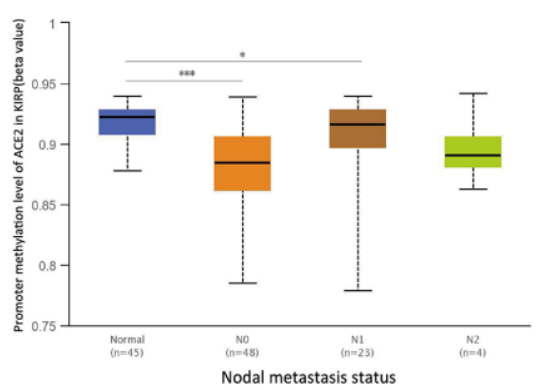

Figure 5. The promoter methylation levels of ACE2 in UCEC and KIRP. Promoter methylation levels of ACE2 were low in (A-E) Uterine Corpus Endometrial Carcinoma (UCEC) and (F-I) Kidney Renal Papillary Cell Carcinoma (KIRP) ( $\left.{ }^{*} \mathrm{P}<0.05,{ }^{* *} \mathrm{P}<0.01,{ }^{* * *} \mathrm{P}<0.001\right)$.

A

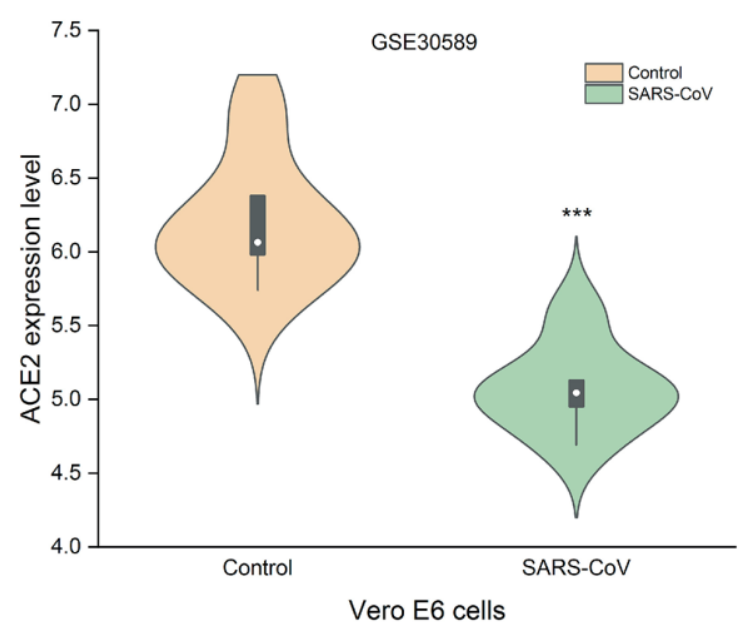

B

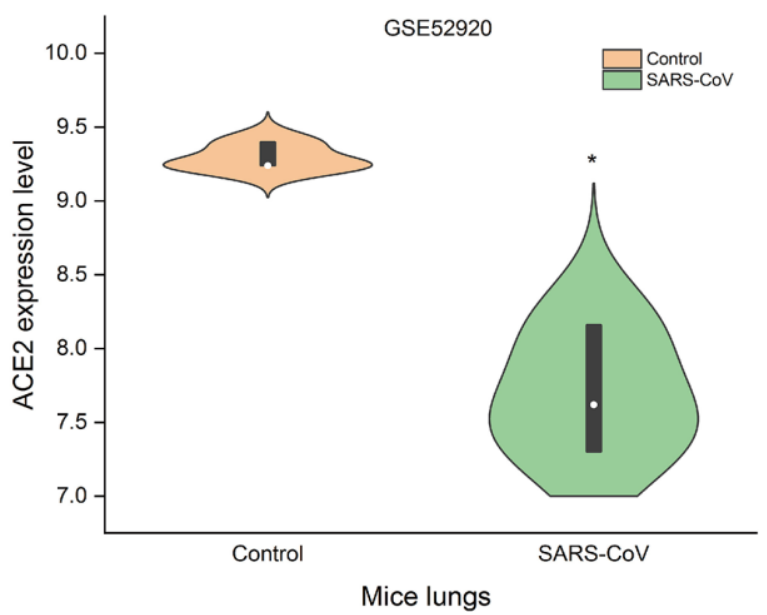

Figure 6. Changes of ACE2 after SARS-CoV infection. SARS-CoV reduced the expression levels of ACE2 in (A) Vero E6 cells and (B) mice lungs $\left({ }^{* * *} \mathrm{P}<0.001,{ }^{*} \mathrm{P}<0.05\right.$ vs. Control). 
immune infiltration, which may worsen the prognoses of UCEC and KIRP patients after SARS-CoV-2 infection.

As an important member of the renin-angiotensin system (RAS), ACE2 has shown different roles in some pathological processes. One study showed that overexpression of ACE2 can protect endothelial cells by inhibiting the inflammatory response, which is beneficial to early prevention of atherosclerosis [36]. Walters et al. [37] found a direct relationship between atrial structural remodeling and plasma ACE2 activity in patients with atrial fibrillation. While ACE2 not only affects the progress of cardiovascular diseases, but also plays a new role in tumor pathology. $\mathrm{Yu} \mathrm{C}$ et al. [20] found that down-regulating the ACE2/Ang-(1-7)/Mas axis caused breast cancer metastasis by activating store-operated calcium entry (SOCE) and PAK1/NF- $\kappa \mathrm{B} /$ Snail1 pathways. ACE2 also down-regulates VEGFa expression in breast cancer cells and inactivates phosphorylation of VEGFR2, MEK1/2 and ERK1/2 in human umbilical endothelial cells, furthermore, ACE2 can prevent breast cancer cell metastasis in zebrafish models [38]. A study carried out by Yu X et al. [39] showed that ACE2 can block the inflammatory response of pancreatic acinar cells by blocking the p38 MAPK/NF- $\kappa \mathrm{B}$ signaling pathway. $\mathrm{Li} \mathrm{J}$ et al. [40] examined the role of ACE2 and FZD1 in squamous cell/adenosquamous carcinoma (SC / ASC) of the gallbladder, the results showed that negative ACE2 expression in SC/ASC was associated with high TNM stage and lymph node metastasis, and survival analysis showed ACE2 and SC/ASC overall survival were positively correlated. ACE2 was also decreased in nonsmall cell lung cancer (NSCLC), but overexpression of ACE2 in vitro exerted protective effects by inhibiting cell growth and VEGFa production [41]. In addition, ACE2 overexpression in non-small cell lung cancer can inhibit tumor angiogenesis induced by acquired platinum resistance [42]. In general, ACE2 mainly affected tumor metastasis by intervening signaling pathways, but the mechanism by which ACE2 affected the prognosis of UCEC and KIRP is unclear. Here, we found that ACE2 may affect the prognosis of UCEC and KIRP through a new mechanism, that was, immune infiltration, which can provide a direction for future in-depth research. But this research also has some limitations, due to the limitation of the database, we did not continue to analyze the deep relationship between ACE2 and immune infiltration. Also, experiments are urgently needed to verify the analysis results in our research.

\section{CONCLUSIONS}

To sum up, ACE2 expression increased significantly in UCEC and KIRP. Elevated ACE2 was positively correlated with immune infiltration and prognoses of UCEC and KIRP. Moreover, tumor tissues were more susceptible to SARS-CoV-2 infection in COVID-19 patients with UCEC and KIRP. In the end, tumor tissues infected with SARS-CoV-2 may undergo a decrease in ACE2, and reduced ACE2 can bring about reduced immune infiltration in the tumor microenvironment, which may worsen the prognosis of COVID-19 patients with UCEC and KIRP.

\section{MATERIALS AND METHODS}

\section{Oncomine database analysis}

ACE2 expression in different tumors was identified in the Oncomine database (https://www.oncomine.org/ resource/main.html) [27]. The threshold was a P-value of 0.01 , a 1.5-fold change, and a top $10 \%$ of gene ranking. The data must come from mRNA.

\section{Survival analysis in PrognoScan, GEPIA and Kaplan-Meier plotter databases}

To analyze the prognosis of ACE2 expression in various tumors, PrognoScan (http://dna00.bio.kyutech.ac.jp/ PrognoScan/index.html) [28], GEPIA (http://gepia. cancer-pku.cn/) [29] and Kaplan-Meier plotter (http://kmplot.com/) [30] databases were used separately. This threshold was cox $\mathrm{p}$-value $<0.05$ in PrognoScan database, logrank $\mathrm{p}$ value $<0.05$ in GEPIA and Kaplan-Meier plotter database.

\section{TIMER database analysis}

TIMER is a comprehensive database that can analyze the levels of immune invasion in different tumors and the differences in gene expression of different tumors (https://cistrome.shinyapps.io/timer/) [31]. We confirmed the expression of ACE2 in various tumors using the TIMER database. Then the correlation of ACE2 with immune infiltration (B cells, CD4 + T cells, CD8 + T cells, Neutrophils, Macrophages, and Dendritic cells) in the tumor was estimated using the TIMER algorithm. Finally, the correlation of ACE2 with the type markers of B-cells, CD8 + T cells, neutrophils, macrophages, dendritic cells NK cells, Th1 cells, Treg cells and monocytes in UCEC and KIRP were verified. In addition, we used tumor purity and patient's age for $\mathrm{p}$ value correction.

\section{UALCAN database analysis}

UALCAN is a comprehensive interactive web resource for analyzing cancer OMICS data (http://ualcan. path.uab.edu/index.html) [32]. It is built on PERL-CGI and can be used to assess the methylation levels of 
different genes. So the ACE2 promoter methylation profile was tested in the UALCAN database. Moreover, we performed a stratified analysis based on patients' age, individual cancer stages, tumor grade, tumor histology and nodal metastasis status.

\section{Microarray data collection}

GEO (https://www.ncbi.nlm.nih.gov/geo/) is a public repository that can archive microarrays and other forms of high-throughput functional genomics data, and the expression profiles of GSE30589 and GSE52920 were obtained in the GEO database. The GSE30589 database which contained 12 SARS-CoV infected samples and 9 control samples was based on the GPL570 platform ([HG-U133_Plus_2] Affymetrix Human Genome U133 Plus 2.0 Array). While the GSE52920 database which included 3 lung tissue samples of mice infected with SARS-CoV and 3 normal mice lung tissue samples was based on the GPL13912 platform (Agilent-028005 SurePrint G3 Mouse GE 8x60K Microarray).

\section{Statistical analysis}

The statistical results of the survival analysis were obtained from a log-rank test, and the correlations of ACE2 with immune infiltration and type markers of immune cells were evaluated using Spearman's correlation. Student's t test was used to compare two independent samples. p-values less than 0.05 were considered statistically significant.

\section{Abbreviations}

ACC: Adrenocortical Carcinoma; BLCA: Bladder Urothelial Carcinoma; BRCA: Breast Invasive Carcinoma; CESC: Cervical and Endocervical Cancer; CHOL: Cholangiocarcinoma; COAD: Colon Adenocarcinoma; DLBC: Diffuse Large B-cell Lymphoma; ESCA: Esophageal Carcinoma; GBM: Glioblastoma Multiforme; HNSC: Head and Neck Cancer; KICH: Kidney Chromophobe; KIRC: Kidney Renal Clear Cell Carcinoma; KIRP: Kidney Renal Papillary Cell Carcinoma; LGG: Lower Grade Glioma; LIHC: Liver Hepatocellular Carcinoma; LUAD: Lung Adenocarcinoma; LUSC: Lung Squamous Cell Carcinoma; MESO: Mesothelioma; OV: Ovarian Serous Cystadenocarcinoma; PAAD: Pancreatic Adenocarcinoma; PCPG: Pheochromocytoma and Paraganglioma; PRAD: Prostate Adenocarcinoma; READ: Rectum Adenocarcinoma; SARC: Sarcoma; SKCM: Skin Cutaneous Melanoma; STAD: Stomach Adenocarcinoma; TGCT: Testicular Germ Cell Tumors; THCA: Thyroid Carcinoma; THYM: Thymoma; UCEC: Uterine Corpus Endometrial Carcinoma; UCS: Uterine Carcinosarcoma; UVM: Uveal Melanoma; NK cells:
Natural killer cells; Th 1 cells: typeIhelper T cells; Treg: regulatory $\mathrm{T}$ cells.

\section{CONFLICTS OF INTEREST}

The authors declare no conflicts of interest.

\section{FUNDING}

This work was supported by grants from National Natural Science Foundation of China (81873486, 81770327), Natural Scientific Fund of Jiangsu province (BK20161226), Jiangsu Province, s Key Provincial Talents Program (ZDRCA2016043), Jiangsu Province, s 333 High-Level Talents Project (BRA2017539), Jiangsu Provincial Medical Innovation Team (NO.CXTDA2017009). The funders had no roles in study design, data collection and analysis, decision to publish, or preparation of the manuscript.

\section{REFERENCES}

1. Siegel RL, Miller KD, Jemal A. Cancer statistics, 2018. CA Cancer J Clin. 2018; 68:7-30. https://doi.org/10.3322/caac.21442 PMID:29313949

2. Tsikouras P, Bouchlariotou S, Vrachnis N, Dafopoulos A, Galazios G, Csorba R, von Tempelhoff GF. Endometrial cancer: molecular and therapeutic aspects. Eur J Obstet Gynecol Reprod Biol. 2013; 169:1-9. https://doi.org/10.1016/i.ejogrb.2013.01.018 PMID:23433742

3. Torre LA, Bray F, Siegel RL, Ferlay J, Lortet-Tieulent J, Jemal A. Global cancer statistics, 2012. CA Cancer J Clin. 2015; 65:87-108.

https://doi.org/10.3322/caac.21262

PMID:25651787

4. Chen W, Zheng R, Baade PD, Zhang S, Zeng H, Bray F, Jemal A, Yu XQ, He J. Cancer statistics in China, 2015. CA Cancer J Clin. 2016; 66:115-32.

https://doi.org/10.3322/caac.21338

PMID:26808342

5. Morice P, Leary A, Creutzberg C, Abu-Rustum N, Darai E. Endometrial cancer. Lancet. 2016; 387:1094-108. https://doi.org/10.1016/S0140-6736(15)00130-0 PMID:26354523

6. Bokhman JV. Two pathogenetic types of endometrial carcinoma. Gynecol Oncol. 1983; 15:10-17. https://doi.org/10.1016/0090-8258(83)90111-7 PMID:

7. Carlson JW, Nastic D. High-Grade Endometrial Carcinomas: Classification with Molecular Insights. Surg Pathol Clin. 2019; 12:343-62. 
https://doi.org/10.1016/j.path.2019.02.003

PMID:31097108

8. Chaudhry P, Asselin E. Resistance to chemotherapy and hormone therapy in endometrial cancer. Endocr Relat Cancer. 2009; 16:363-80.

https://doi.org/10.1677/ERC-08-0266

PMID: 19190080

9. Pakish JB, Zhang $Q$, Chen Z, Liang $H$, Chisholm GB, Yuan Y, Mok SC, Broaddus RR, Lu KH, Yates MS. Immune Microenvironment in Microsatellite-Instable Endometrial Cancers: Hereditary or Sporadic Origin Matters. Clin Cancer Res. 2017; 23:4473-81. https://doi.org/10.1158/1078-0432.CCR-16-2655 PMID:28264871

10. Malouf GG, Su X, Zhang J, Creighton CJ, Ho TH, Lu Y, Raynal NJ, Karam JA, Tamboli P, Allanick F, Mouawad $R$, Spano JP, Khayat D, et al. DNA Methylation Signature Reveals Cell Ontogeny of Renal Cell Carcinomas. Clin Cancer Res. 2016; 22:6236-46. https://doi.org/10.1158/1078-0432.CCR-15-1217 PMID:27256309

11. Courthod G, Tucci M, Di Maio M, Scagliotti GV. Papillary renal cell carcinoma: A review of the current therapeutic landscape. Crit Rev Oncol Hematol. 2015; 96:100-12.

https://doi.org/10.1016/i.critrevonc.2015.05.008 PMID:26052049

12. Delahunt B, Eble JN. Papillary renal cell carcinoma: a clinicopathologic and immunohistochemical study of 105 tumors. Mod Pathol. 1997; 10:537-44.

PMID: 9195569

13. Jiang F, Richter J, Schraml P, Bubendorf L, Gasser T, Sauter G, Mihatsch MJ, Moch H. Chromosomal imbalances in papillary renal cell carcinoma: genetic differences between histological subtypes. Am J Pathol. 1998; 153:1467-73.

https://doi.org/10.1016/S0002-9440(10)65734-3 PMID: 9811338

14. Zhang S, Zhang E, Long J, Hu Z, Peng J, Liu L, Tang F, Li $L$, Ouyang $Y$, Zeng $Z$. Immune infiltration in renal cell carcinoma. Cancer Sci. 2019; 110:1564-72. https://doi.org/10.1111/cas.13996 PMID:30861269

15. Hutterer GC, Pichler M, Chromecki TF, Strini KA, Klatte T, Pummer K, Remzi M, Mannweiler S, Zigeuner R. Tumour-associated macrophages might represent a favourable prognostic indicator in patients with papillary renal cell carcinoma. Histopathology. 2013; 63:309-15.

https://doi.org/10.1111/his.12163

PMID:23802739

16. Tipnis SR, Hooper NM, Hyde R, Karran E, Christie G, Turner AJ. A human homolog of angiotensin- converting enzyme. Cloning and functional expression as a captopril-insensitive carboxypeptidase. J Biol Chem. 2000; 275:33238-43.

https://doi.org/10.1074/ibc.M002615200 PMID:10924499

17. Donoghue M, Hsieh F, Baronas E, Godbout K, Gosselin M, Stagliano N, Donovan M, Woolf B, Robison K, Jeyaseelan R, Breitbart RE, Acton S. A novel angiotensin-converting enzyme-related carboxypeptidase (ACE2) converts angiotensin I to angiotensin 1-9. Circ Res. 2000; 87:E1-9.

https://doi.org/10.1161/01.RES.87.5.e1 PMID:10969042

18. Pernomian L, Pernomian L, Baraldi Araújo Restini C. Counter-regulatory effects played by the ACE - Ang II AT1 and ACE2 - Ang-(1-7) - Mas axes on the reactive oxygen species-mediated control of vascular function: perspectives to pharmacological approaches in controlling vascular complications. Vasa. 2014; 43:404-14.

https://doi.org/10.1024/0301-1526/a000387 PMID:25339158

19. Zhou L, Zhang R, Zhang L, Yao W, Li J, Yuan Y. Angiotensin-converting enzyme 2 acts as a potential molecular target for pancreatic cancer therapy. Cancer Lett. 2011; 307:18-25.

https://doi.org/10.1016/j.canlet.2011.03.011 PMID:21481527

20. Yu C, Tang W, Wang $Y$, Shen $Q$, Wang B, Cai C, Meng X, Zou F. Downregulation of ACE2/Ang-(1-7)/Mas axis promotes breast cancer metastasis by enhancing store-operated calcium entry. Cancer Lett. 2016; 376:268-77.

https://doi.org/10.1016/i.canlet.2016.04.006 PMID:27063099

21. Bernardi S, Zennaro C, Palmisano S, Velkoska E, Sabato N, Toffoli B, Giacomel G, Buri L, Zanconati F, Bellini G, Burrell LM, De Manzini N, Fabris B. Characterization and significance of ACE2 and Mas receptor in human colon adenocarcinoma. J Renin Angiotensin Aldosterone Syst. 2012; 13:202-09. https://doi.org/10.1177/1470320311426023 PMID:22048948

22. Li $Q$, Guan $X$, Wu $P$, Wang $X$, Zhou $L$, Tong $Y$, Ren $R$, Leung KS, Lau EH, Wong JY, Xing $X$, Xiang N, Wu Y, et al. Early Transmission Dynamics in Wuhan, China, of Novel Coronavirus-Infected Pneumonia. N Engl J Med. 2020; 382:1199-207. [Epub ahead of print]. https://doi.org/10.1056/NEJMoa2001316 PMID:31995857

23. Lu R, Zhao X, Li J, Niu P, Yang B, Wu H, Wang W, Song H, Huang B, Zhu N, Bi Y, Ma X, Zhan F, et al. Genomic characterisation and epidemiology of 2019 novel 
coronavirus: implications for virus origins and receptor binding. Lancet. 2020; 395:565-74.

https://doi.org/10.1016/S0140-6736(20)30251-8

PMID:32007145

24. Zhou $P$, Yang $X L$, Wang $X G$, Hu B, Zhang L, Zhang $W, S i$ $H R$, Zhu Y, Li B, Huang CL, Chen HD, Chen J, Luo Y, et al. A pneumonia outbreak associated with a new coronavirus of probable bat origin. Nature. 2020; 579:270-73.

https://doi.org/10.1038/s41586-020-2012-7

PMID:32015507

25. National Health Commission of the People's Republic of China. http://www.nhc.gov.cn

26. WHO main website. https://www.who.int

27. Rhodes DR, Kalyana-Sundaram S, Mahavisno V, Varambally R, Yu J, Briggs BB, Barrette TR, Anstet MJ, Kincead-Beal C, Kulkarni P, Varambally S, Ghosh D, Chinnaiyan AM. Oncomine 3.0: genes, pathways, and networks in a collection of 18,000 cancer gene expression profiles. Neoplasia. 2007; 9:166-80. https://doi.org/10.1593/neo.07112 PMID:17356713

28. Mizuno H, Kitada K, Nakai K, Sarai A. PrognoScan: a new database for meta-analysis of the prognostic value of genes. BMC Med Genomics. 2009; 2:18.

https://doi.org/10.1186/1755-8794-2-18 PMID:19393097

29. Tang Z, Li C, Kang B, Gao G, Li C, Zhang Z. GEPIA: a web server for cancer and normal gene expression profiling and interactive analyses. Nucleic Acids Res. 2017; 45:W98-102.

https://doi.org/10.1093/nar/gkx247

PMID:28407145

30. Györffy B, Lanczky A, Eklund AC, Denkert C, Budczies J, Li $Q$, Szallasi Z. An online survival analysis tool to rapidly assess the effect of 22,277 genes on breast cancer prognosis using microarray data of 1,809 patients. Breast Cancer Res Treat. 2010; 123:725-31. https://doi.org/10.1007/s10549-009-0674-9 PMID:20020197

31. Li T, Fan J, Wang B, Traugh N, Chen Q, Liu JS, Li B, Liu XS. TIMER: A Web Server for Comprehensive Analysis of Tumor-Infiltrating Immune Cells. Cancer Res. 2017; 77:e108-10.

https://doi.org/10.1158/0008-5472.CAN-17-0307

PMID:29092952

32. Chandrashekar DS, Bashel B, Balasubramanya SA, Creighton CJ, Ponce-Rodriguez I, Chakravarthi BV, Varambally S. UALCAN: A Portal for Facilitating Tumor Subgroup Gene Expression and Survival Analyses. Neoplasia. 2017; 19:649-58.

https://doi.org/10.1016/j.neo.2017.05.002

PMID:28732212
33. Heyn $H$, Esteller M. DNA methylation profiling in the clinic: applications and challenges. Nat Rev Genet. 2012; 13:679-92. https://doi.org/10.1038/nrg3270 PMID:22945394

34. Robertson KD. DNA methylation and human disease. Nat Rev Genet. 2005; 6:597-610. https://doi.org/10.1038/nrg1655 PMID: 16136652

35. Costello JF, Frühwald MC, Smiraglia DJ, Rush L, Robertson GP, Gao X, Wright FA, Feramisco JD, Peltomäki P, Lang JC, Schuller DE, Yu L, Bloomfield CD, et al. Aberrant CpG-island methylation has nonrandom and tumour-type-specific patterns. Nat Genet. 2000; 24:132-38.

https://doi.org/10.1038/72785

PMID: 10655057

36. Zhang $Y H$, Zhang $Y H$, Dong $X F$, Hao $Q Q$, Zhou XM, Yu QT, Li SY, Chen X, Tengbeh AF, Dong B, Zhang Y. ACE2 and Ang-(1-7) protect endothelial cell function and prevent early atherosclerosis by inhibiting inflammatory response. Inflamm Res. 2015; 64:253-60. https://doi.org/10.1007/s00011-015-0805-1 PMID:25721616

37. Walters TE, Kalman JM, Patel SK, Mearns M, Velkoska $\mathrm{E}$, Burrell LM. Angiotensin converting enzyme 2 activity and human atrial fibrillation: increased plasma angiotensin converting enzyme 2 activity is associated with atrial fibrillation and more advanced left atrial structural remodelling. Europace. 2017; 19:1280-87. https://doi.org/10.1093/europace/euw246 PMID:27738071

38. Zhang $Q$, Lu S, Li T, Yu L, Zhang Y, Zeng H, Qian X, Bi J, Lin Y. ACE2 inhibits breast cancer angiogenesis via suppressing the VEGFa/VEGFR2/ERK pathway. J Exp Clin Cancer Res. 2019; 38:173. https://doi.org/10.1186/s13046-019-1156-5 PMID:31023337

39. Yu X, Cui L, Hou F, Liu X, Wang Y, Wen Y, Chi C, Li C, Liu $R$, Yin $C$. Angiotensin-converting enzyme 2-angiotensin (1-7)-Mas axis prevents pancreatic acinar cell inflammatory response via inhibition of the p38 mitogen-activated protein kinase/nuclear factor-KB pathway. Int J Mol Med. 2018; 41:409-20.

https://doi.org/10.3892/ijmm.2017.3252 PMID:29138810

40. Li J, Yang ZL, Ren X, Zou Q, Yuan Y, Liang L, Chen M, Chen S. ACE2 and FZD1 are prognosis markers in squamous cell/adenosquamous carcinoma and adenocarcinoma of gallbladder. J Mol Histol. 2014; 45:47-57.

https://doi.org/10.1007/s10735-013-9528-1

PMID:23921915 
41. Feng $Y$, Wan $H$, Liu J, Zhang $R$, Ma $Q$, Han $B$, Xiang $Y$, Che J, Cao H, Fei X, Qiu W. The angiotensin-converting enzyme 2 in tumor growth and tumor-associated angiogenesis in non-small cell lung cancer. Oncol Rep. 2010; 23:941-48.

https://doi.org/10.3892/or 00000718

PMID:20204277
42. Cheng $\mathrm{Q}$, Zhou L, Zhou J, Wan H, Li Q, Feng Y. ACE2 overexpression inhibits acquired platinum resistanceinduced tumor angiogenesis in NSCLC. Oncol Rep. 2016; 36:1403-10.

https://doi.org/10.3892/or.2016.4967

PMID:27460845 


\section{SUPPLEMENTARY MATERIALS}

\section{Supplementary Figures}
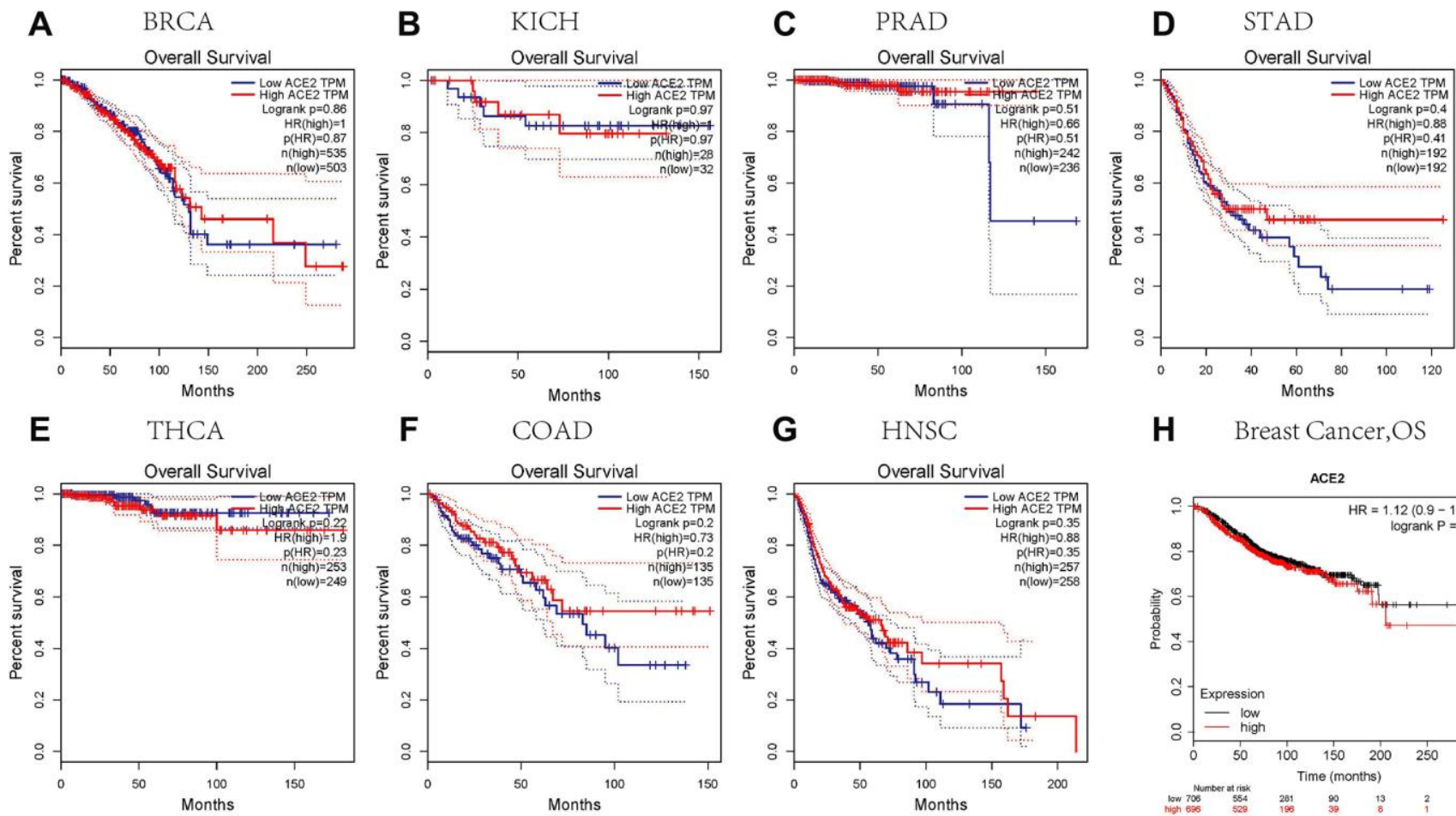

G HNSC

H Breast Cancer,OS
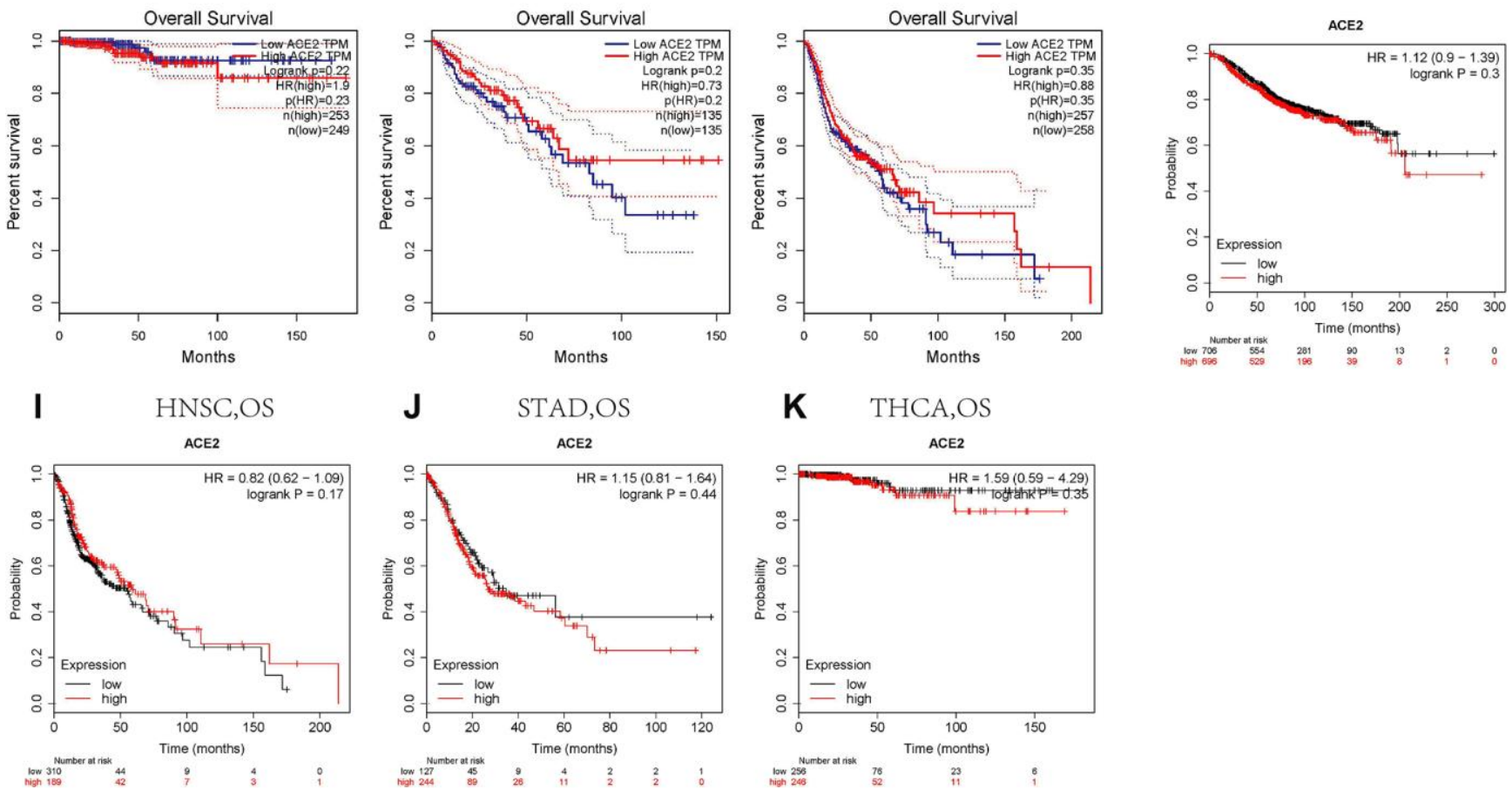

Supplementary Figure 1. Correlations between ACE2 expression and immune infiltration in different cancers. Comparison of overall survival of ACE2 over-expression and under-expression in (A-G) Breast Invasive Carcinoma (BRCA), Kidney Chromophobe (KICH), Prostate Adenocarcinoma (PRAD), Stomach Adenocarcinoma (STAD), Thyroid Carcinoma (THCA), Colon Adenocarcinoma (COAD) and Head and Neck Cancer (HNSC) in GEPIA database, (H-K) Breast Cancer, Head and Neck Cancer (HNSC), Stomach Adenocarcinoma (STAD) and Thyroid Carcinoma (THCA) in Kaplan Meier plotter database. 


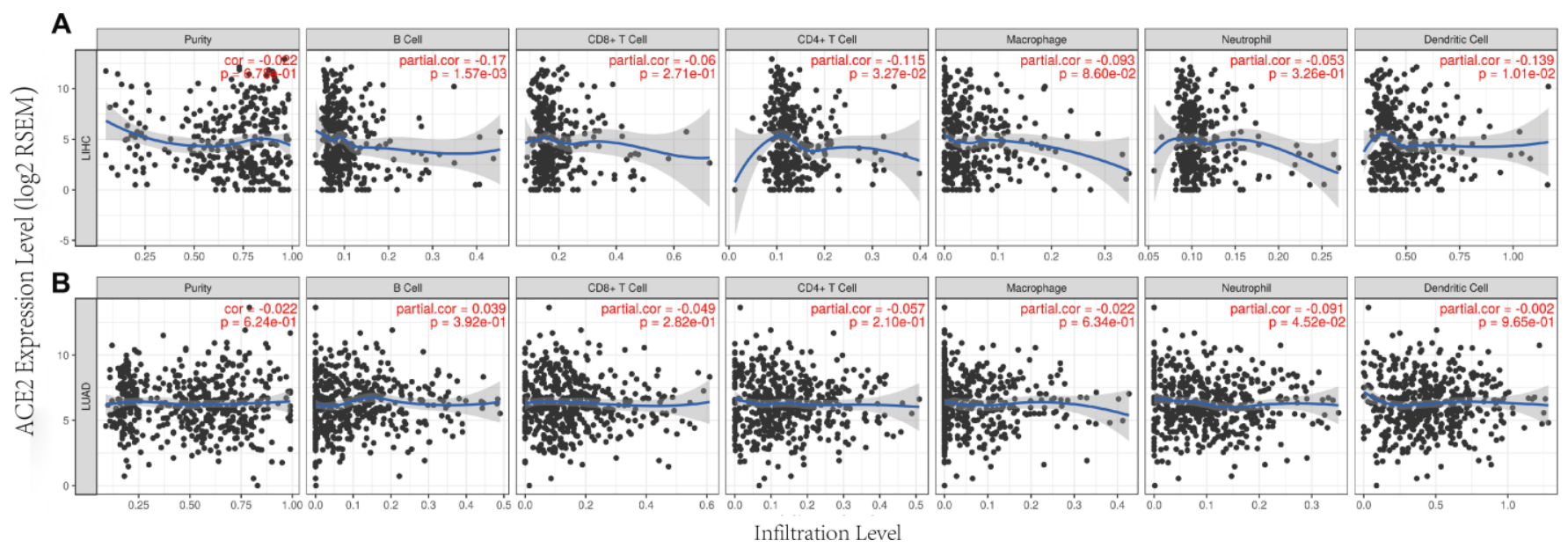

Supplementary Figure 2. Correlation between ACE2 expression and immune infiltration in LIHC and LUAD in TIMER database. ACE2 was very weakly negatively correlated with (A) B cell, CD4 + T cell, dendritic cell of Liver hepatocellular carcinoma (LIHC), and (B) neurophil of lung adenocarcinoma (LUAD). 


\section{Supplementary Tables}

Supplementary Table 1. The expression levels of ACE2 in Oncome database compared with normal tissues.

\begin{tabular}{|c|c|c|c|c|c|c|}
\hline Cancer & Cancer subtype & P-value & $\begin{array}{c}\text { Fold } \\
\text { change }\end{array}$ & $\begin{array}{c}\text { Rank } \\
(\%)\end{array}$ & Sample & $\begin{array}{c}\text { Reference } \\
\text { (PMID) }\end{array}$ \\
\hline & Invasive Breast Carcinoma & $2.11 \mathrm{E}-16$ & 2.279 & $4 \%$ & 725 & 18438415 \\
\hline & Invasive Ductal Breast Carcinoma & $1.11 \mathrm{E}-4$ & -1.751 & $2 \%$ & 324 & 19187537 \\
\hline & Invasive Lobular Breast Carcinoma & $1.93 \mathrm{E}-11$ & -3.134 & $5 \%$ & 931 & TCGA \\
\hline & Invasive Ductal Breast Carcinoma & $9.75 \mathrm{E}-26$ & -2.684 & $6 \%$ & 1124 & TCGA \\
\hline & $\begin{array}{c}\text { Intraductal Cribriform Breast } \\
\text { Adenocarcinoma }\end{array}$ & 0.008 & -5.450 & $10 \%$ & 2016 & TCGA \\
\hline & Colon Mucinous Adenocarcinoma & $9.11 \mathrm{E}-5$ & -2.690 & $8 \%$ & 1413 & 17615082 \\
\hline & Colon Adenoma & $8.55 \mathrm{E}-5$ & -3.739 & $9 \%$ & 1650 & 20957034 \\
\hline & Barrett's Esophagus & $1.21 \mathrm{E}-4$ & 3.893 & $10 \%$ & 1820 & 21152079 \\
\hline & Esophageal Adenocarcinoma & 0.002 & -5.143 & $3 \%$ & 445 & 16952561 \\
\hline & Barrett's Esophagus & 0.006 & -2.947 & $4 \%$ & 560 & 16952561 \\
\hline \multirow[t]{12}{*}{$\begin{array}{l}\text { Head and } \\
\text { Neck cancer }\end{array}$} & Tongue Squamous Cell Carcinoma & 0.002 & 1.537 & $10 \%$ & 1763 & 18254958 \\
\hline & Renal Wilms Tumor & $4.08 \mathrm{E}-4$ & -64.062 & $1 \%$ & 156 & 20440404 \\
\hline & Chromophobe Renal Cell Carcinoma & 0.003 & -21.769 & $4 \%$ & 779 & 20440404 \\
\hline & Renal Oncocytoma & 0.003 & -13.376 & $5 \%$ & 958 & 20440404 \\
\hline & Chromophobe Renal Cell Carcinoma & $1.50 \mathrm{E}-10$ & -5.131 & $2 \%$ & 212 & 16115910 \\
\hline & Renal Pelvis Urothelial Carcinoma & $1.12 \mathrm{E}-6$ & -3.856 & $7 \%$ & 841 & 16115910 \\
\hline & Renal Oncocytoma & $1.17 \mathrm{E}-7$ & -4.528 & $9 \%$ & 1026 & 16115910 \\
\hline & Renal Wilms Tumor & 0.005 & -1.959 & $7 \%$ & 843 & 16299227 \\
\hline & Clear Cell Sarcoma of the Kidney & 0.010 & -2.843 & $10 \%$ & 1255 & 16299227 \\
\hline & Cirrhosis & $5.12 \mathrm{E}-4$ & 2.842 & $5 \%$ & 874 & 17393520 \\
\hline & Liver Cell Dysplasia & 0.005 & 1.956 & $5 \%$ & 969 & 17393520 \\
\hline & Cirrhosis & $6.51 \mathrm{E}-9$ & 1.755 & $9 \%$ & 1054 & 19098997 \\
\hline \multirow[t]{15}{*}{ Lung cancer } & Lung Adenocarcinoma & $1.36 \mathrm{E}-11$ & 2.039 & $5 \%$ & 866 & 23028479 \\
\hline & $\begin{array}{c}\text { Germinal Center B-Cell-Like Diffuse } \\
\text { Large B-Cell Lymphoma }\end{array}$ & $2.94 \mathrm{E}-11$ & -1.872 & $1 \%$ & 118 & \\
\hline & $\begin{array}{l}\text { Activated B-Cell-Like Diffuse Large B- } \\
\text { Cell Lymphoma }\end{array}$ & $1.06 \mathrm{E}-10$ & -1.841 & $3 \%$ & 556 & \\
\hline & Follicular Lymphoma & $1.81 \mathrm{E}-9$ & -1.649 & $9 \%$ & 1568 & \\
\hline & Diffuse Large B-Cell Lymphoma & $2.15 \mathrm{E}-10$ & -1.809 & $10 \%$ & 1800 & \\
\hline & Testicular Intratubular Germ Cell Neoplasi & 0.009 & 4.922 & $2 \%$ & 170 & 15994931 \\
\hline & Yolk Sac Tumor & $1.61 \mathrm{E}-12$ & -17.251 & $1 \%$ & 25 & \\
\hline & Seminoma & $3.01 \mathrm{E}-12$ & -14.554 & $1 \%$ & 46 & \\
\hline & Mixed Germ Cell Tumor & $1.48 \mathrm{E}-19$ & -12.891 & $1 \%$ & 50 & \\
\hline & Embryonal Carcinoma & $2.54 \mathrm{E}-10$ & -13.188 & $2 \%$ & 282 & \\
\hline & Testicular Embryonal Carcinoma & $3.39 \mathrm{E}-4$ & -23.719 & $4 \%$ & 477 & \\
\hline & Testicular Yolk Sac Tumor & $6.09 \mathrm{E}-4$ & -20.922 & $4 \%$ & 554 & \\
\hline & Testicular Seminoma & 0.001 & -30.784 & $6 \%$ & 809 & \\
\hline & Uterine Corpus Leiomyoma & $3.01 \mathrm{E}-4$ & -1.641 & $5 \%$ & 799 & 19622772 \\
\hline & Malignant Fibrous Histiocytoma & 0.003 & -3.649 & $9 \%$ & 1058 & $\begin{array}{c}15994966, \\
16603191\end{array}$ \\
\hline $\begin{array}{l}\text { pancreatic } \\
\text { cancer }\end{array}$ & Pancreatic Ductal Adenocarcinoma & 0.006 & -2.373 & $2 \%$ & 333 & 16053509 \\
\hline
\end{tabular}




\begin{tabular}{ccccccc} 
& Malignant Fibrous Histiocytoma & 0.003 & -3.649 & $9 \%$ & 1058 & 15994966, \\
16603191 \\
sarcoma & Clear Cell Sarcoma of the Kidney & 0.010 & 2.843 & $10 \%$ & 1255 & 16299227 \\
& & & & & 21447720, \\
& & & & & \\
Gastrointestinal Stromal Tumor & $8.51 \mathrm{E}-5$ & -3.067 & $7 \%$ & 1335 & 29725014, \\
& & & & & & 23112551 \\
\hline
\end{tabular}

Supplementary Table 2. Relationships between ACE2 expressions and prognoses in different cancers in PrognoScan database.

\begin{tabular}{|c|c|c|c|c|c|c|}
\hline DATASET & $\begin{array}{c}\text { CANCER } \\
\text { TYPE }\end{array}$ & SUBTYPE & ENDPOINT & $\mathbf{N}$ & $\begin{array}{c}\text { COX } \\
\text { P-VALUE }\end{array}$ & HR [95\% CI-low CI-upp] \\
\hline GSE9893 & $\begin{array}{l}\text { Breast } \\
\text { cancer }\end{array}$ & - & Overall Survival & 155 & 0.207469 & $0.83[0.61-1.11]$ \\
\hline $\begin{array}{l}\text { GSE1456- } \\
\text { GPL96 }\end{array}$ & $\begin{array}{l}\text { Breast } \\
\text { cancer }\end{array}$ & - & Overall Survival & 159 & 0.749893 & $1.05[0.78-1.40]$ \\
\hline $\begin{array}{l}\text { GSE1456- } \\
\text { GPL96 }\end{array}$ & $\begin{array}{l}\text { Breast } \\
\text { cancer }\end{array}$ & - & Overall Survival & 159 & 0.24964 & $1.28[0.84-1.93]$ \\
\hline $\begin{array}{l}\text { E-TABM- } \\
158\end{array}$ & $\begin{array}{l}\text { Breast } \\
\text { cancer }\end{array}$ & - & Overall Survival & 117 & 0.263366 & $1.39[0.78-2.47]$ \\
\hline $\begin{array}{l}\text { E-TABM- } \\
158\end{array}$ & $\begin{array}{l}\text { Breast } \\
\text { cancer }\end{array}$ & - & Overall Survival & 117 & 0.531078 & $1.19[0.69-2.07]$ \\
\hline GSE7390 & $\begin{array}{l}\text { Breast } \\
\text { cancer }\end{array}$ & - & Overall Survival & 198 & 0.002524 & $1.23[1.08-1.41]$ \\
\hline GSE7390 & $\begin{array}{l}\text { Breast } \\
\text { cancer }\end{array}$ & - & Overall Survival & 198 & 0.006852 & $1.18[1.05-1.33]$ \\
\hline GSE12945 & $\begin{array}{l}\text { Colorectal } \\
\text { cancer }\end{array}$ & - & Overall Survival & 62 & 0.081404 & $0.68[0.44-1.05]$ \\
\hline GSE12945 & $\begin{array}{l}\text { Colorectal } \\
\text { cancer }\end{array}$ & - & Overall Survival & 62 & 0.112689 & $0.68[0.43-1.09]$ \\
\hline GSE17536 & $\begin{array}{l}\text { Colorectal } \\
\text { cancer }\end{array}$ & - & Overall Survival & 177 & 0.841356 & $0.98[0.82-1.18]$ \\
\hline GSE17536 & $\begin{array}{l}\text { Colorectal } \\
\text { cancer }\end{array}$ & - & Overall Survival & 177 & 0.929774 & $0.99[0.85-1.16]$ \\
\hline GSE17537 & $\begin{array}{l}\text { Colorectal } \\
\text { cancer }\end{array}$ & - & Overall Survival & 55 & 0.592087 & $1.11[0.75-1.64]$ \\
\hline GSE17537 & $\begin{array}{l}\text { Colorectal } \\
\text { cancer }\end{array}$ & - & Overall Survival & 55 & 0.494492 & $1.11[0.82-1.49]$ \\
\hline GSE11595 & $\begin{array}{l}\text { Esophagus } \\
\text { cancer }\end{array}$ & Adenocarcinoma & Overall Survival & 34 & 0.974499 & $0.98[0.38-2.53]$ \\
\hline GSE2837 & $\begin{array}{l}\text { Head and } \\
\text { neck cancer }\end{array}$ & $\begin{array}{c}\text { Squamous } \\
\text { cell carcinoma }\end{array}$ & $\begin{array}{c}\text { Relapse } \\
\text { Free Survival }\end{array}$ & 28 & 0.308794 & $1.75[0.60-5.12]$ \\
\hline GSE11117 & Lung cancer & NSCLC & Overall Survival & 41 & 0.118476 & $1.37[0.92-2.03]$ \\
\hline GSE3141 & Lung cancer & NSCLC & Overall Survival & 111 & 0.362302 & $0.87[0.63-1.18]$ \\
\hline GSE3141 & Lung cancer & NSCLC & Overall Survival & 111 & 0.542736 & $0.91[0.68-1.22]$ \\
\hline GSE14814 & Lung cancer & NSCLC & Overall Survival & 90 & 0.973271 & $1.02[0.35-2.93]$ \\
\hline GSE14814 & Lung cancer & NSCLC & Overall Survival & 90 & 0.442885 & $1.52[0.52-4.42]$ \\
\hline GSE4573 & Lung cancer & $\begin{array}{l}\text { Squamous } \\
\text { cell carcinoma }\end{array}$ & Overall Survival & 129 & 0.809129 & $0.94[0.56-1.57]$ \\
\hline GSE17710 & Lung cancer & $\begin{array}{c}\text { Squamous } \\
\text { cell carcinoma }\end{array}$ & Overall Survival & 56 & 0.149829 & $0.76[0.52-1.10]$ \\
\hline
\end{tabular}




\begin{tabular}{ccccccc} 
GSE17710 & Lung cancer & $\begin{array}{c}\text { Squamous } \\
\text { cell carcinoma }\end{array}$ & Overall Survival & 56 & 0.104661 & $0.73[0.50-1.07]$ \\
E-DKFZ-1 & $\begin{array}{c}\text { Renal cell } \\
\text { carcinoma }\end{array}$ & - & Overall Survival & 59 & 0.021041 & $0.17[0.04-0.77]$ \\
\hline
\end{tabular}

